\title{
BOKO HARAM INSURGENCY AND ITS IMPLICATIONS ON THE RIGHTS OF THE FEMALE GENDER IN NIGERIA
}

\author{
O.S. OLUGBENGA, A.E. AYOOLUWA
}

\section{Olugbenga Oke-Samuel}

Faculty of Law

Adekunle Ajasin University, Akungba-Akoko, Nigeria

LL.B (Lagos, Nigeria), LL.M (Lagos, Nigeria),

LL.D (Zululand, South Africa), B.L (Lagos, Nigeria)

Email:1awville@yahoo.com

Telephone: +2348034712290

\section{S. Ayooluwa St. Emmanuel}

Faculty of Law

Adekunle Ajasin University, Akungba-Akoko, Nigeria

LL.B (Akungba-Akoko, Nigeria) LL.M (Ibadan, Nigeria) B.L (Kano, Nigeria)

Email: : kristalplus@yahoo.com / simon.stemmanuel@aaua.edu.ng

Telephone: $+2347030166377 /+2348186530667$

\section{ABSTRACT:}

The Boko Haram insurgency in Northern Nigeria and counter-insurgency measures adopted by the Nigerian Government has caused humanitarian crises and wanton destruction, thereby having adverse impact on the Nigerian nation and its citizenry especially the female gender. The situation has aggravated and degenerated into internal displacement, loss of livelihood and criminal acts such as abduction, murder and rape. This paper examines the various human rights violations perpetrated on the female gender as a result of the insurgency and counter-insurgency operations, it highlights the various women and girls' rights instruments and in conclusion, posits that gender equality, economic empowerment for female folks, partnership with foreign superpowers and adopting an effective intelligence network are possible means of putting a stop to the insurgency and reducing its effect on the female gender in the Country.

KEYWORDS: BOKO HARAM, INSURGENCY, COUNTER-INSURGENCY, NIGERIA, FEMALE GENDER, RIGHTS

\section{INTRODUCTION}

The Terrorism can be said to be the antithesis of human rights and the greatest threat to universal peace and stability in contemporary times. The international community's response to terrorism has been the gradual development, since 1963, of a legal infrastructure of 16 terrorism-related conventions and protocols, multilateral treaties, supplemental agreements and series of Security Council resolutions relating to terrorism, many of them adopted under the authority of chapter VII of the United Nations Charter, which empowers the Security Council to adopt resolutions legally binding on all Member States of the United Nations. ${ }^{1}$

Nigeria, the most populous country in Sub-Saharan Africa, with an estimated population of $182,425,202$, out of which $90,049,168$ are females (49.4 percent of the total population), ${ }^{2}$ is

\footnotetext{
${ }^{1}$ United Nations Office on Drugs and Crime (UNODC); Legislative Guide to the Universal Legal Regime against terrorism (2008). Available at www.unodc.org/terrorism/legislative accessed on 3rd March, 2015.

${ }^{2}$ Available at http://countrymeters.info/en/Nigeria. Accessed on 14th January, 2016.
} 
presently facing terrorism as a result of an ongoing sectarian insurgency, which is spear headed by the Jama'atu Ahlis Sunna Lidda'awati Wal-Jihadl sect also known as Boko Haram, whose intention is to create an Islamic state in Northern Nigeria, that will address the ills of the society and whose nucleus belief are the strict adherence to the Holy Quran and Hadith and their interpretation by Ahmad ibn Taymiyyah (1268-1328 CE). ${ }^{3}$ The insurgency and Nigerian Government's response to it through the use of the military in internal security operations due to the ineffectiveness of the Nigerian police has, left hundreds dead, destroyed human habitations and means of livelihood. It has also caused internal displacement, abduction, rape, physical abuse, human trafficking and forced marriages on the female gender. The insurgency and counter-insurgency operations pose major challenges to the protection of the rights of the female gender in the North-Eastern part of Nigeria as a result of the collapse of social and moral order. These challenges affect the substance of human rights norm and their scope of application. This work in the subsequent sections, will examine the rights of the female gender violated by insurgency and counter-insurgency operations. It also highlights the legal framework for the protection of the female gender and concludes with necessary recommendations.

\section{DEFINITION OF KEY TERMS}

Gender: is a social construct which is not necessarily synonymous with women but for the purpose of this paper, gender connotes the female gender and it will be used interchangeably with the word "women".

Gender based violence: "is violence directed against women based on their subordinate status in society. It includes any act by males or male-dominated social institutions that inflict physical or psychological harm on women or girls because of their gender. It is violence intended to establish or reinforce gender hierarchies and perpetuate gender inequalities including harmful traditional practices targeting women such as honour killings, acid throwing, female genital mutilation (FGM) and forced marriage"4

Insurgency: is "an attempt to take control of a country by force."

Reproductive Rights: 'Reproductive Rights rest on the recognition of the basic right of all couples and individuals to decide freely and responsibly the number, spacing and timing of their children and to have the information and means to do so, and the right to attain the highest standard of sexual and reproductive health. They also include the right of all to make decisions concerning reproduction free of discrimination, coercion and violence, 6

\footnotetext{
${ }^{3}$ Cook, D; Boko Haram: 'A New Islamic State in Nigeria' Available at www.bakerinstitute.org/.../BI-pubBokoHaram-121114.pdf accessed on $7^{\text {th }}$ November, 2015. See also Africa Report $N^{*} 216$, Curbing Violence in Nigeria (II): The Boko Haram Insurgency (International Crises Group, Brussels, April 2014) 7 cited in Taiwo, E. A; "Boko Haram Terrorism and its Impact on the Right of the Girl-Child to Education in Nigeria" (2013), 2 (1), Akungba Law Journal, 16 - 47 at 24. See further Mohammed, K, 'The Message and Methods of Boko Haram' in Perouse de Montclos, M. (ed), Boko Haram: Islamism, Politics, Security and the State in Nigeria, West African Politics and Society Series Vol. 2 (African Studies Centre, Leiden and French Institute for Research in Africa, University of Ibadan, Ibadan \& Ahmadu Bello University, Zaria, 2014) at 14. Available at https://openaccess.leidenuniv.nl/.../ASC-075287668-3441-01.pdf accessed on $8^{\text {th }}$ September, 2015.

${ }^{4}$ Barkindo, A; Gudaku, B. T \& Wesley, C. K; "Our Bodies, Their Battleground; Boko Haram and Gender-Based Violence against Christian Women and Children in North-Eastern Nigeria since 1999" Available at https://www.worldwidewatchmonitor.org/.../...3117403.pdf accessed on $7^{\text {th }}$ November, 2015

${ }^{5}$ Honby, A. S; “Oxford Advanced Learner's Dictionary of Current English” Oxford University Press, Oxford, $7^{\text {th }}$ Edn.

${ }^{6}$ UN Programme of Action adopted at the International Conference on Population and Development (ICPD), Cairo, 5 - 13 September 1994, UN Doc. A/CONF.171/13 1994, Para 7.3. Available at http://www.choiceforyouth.org/information/sexual-and-reproductive-health-and-rights/official-definitions-ofsexual-and-reproductiv. accessed on 7th April, 2016
} 


\section{Olugbenga Oke-Samuel, S. Ayooluwa St. Emmanuel}

Rights: can be defined as "a power, privilege or immunity guaranteed under a constitution, statutes or decisional laws or claimed as a respect of long usage."7

Terrorism: there is no universally accepted definition of terrorism. However, for the purpose of this paper, terrorism is the 'use of violent action in order to achieve political aims or to force a government to act ${ }^{8}$

\section{THE EMERGENCE AND EVOLUTION OF BOKO HARAM}

The terrorists' attacks of $11^{\text {th }}$ September, $2001^{9}$ have led to the worst backlash in the international protection of human rights since the concept was introduced in the UN charter after the Second World War. In contemporary times, terrorist groups have developed from dependence on State sponsorship. Many of them now operate as non-state actors. These nonstate actors make use of porous borders, interconnected international systems on finance, communications and transit, thereby reaching every corner of the globe. Some of these groups remain focused on local or national political dynamics, while, others seek to affect global change. ${ }^{10}$

One of these groups is a salafi-jihadi sect by the name, Jama'atu Ahlis Sunna Lidda'awati Wal-Jihadl ${ }^{11}$ but popularly known as Boko Haram. ${ }^{12}$ This deadly sect has been waging a sectarian insurgency against the Nigerian State since 2009 though it materialized in 2002. The group started as an Islamic movement under Mohammed Yusuf. It was exemplified by intense speeches of its leader which included verbal attacks on secular authorities. ${ }^{13}$

Vicious altercations between the sect and security forces started in June, 2009, when an encounter between members of the sect and a joint police and military unit known as 'Operation Flush' over the enforcement of a government law that made compulsory, the use of helmets by all motorcyclists, turned violent. ${ }^{14}$ As a result, about 17 members of sect were shot and injured by security operatives during the fracas. ${ }^{15}$

Consequently and due to infuriation, the sect resorted to sporadic violent attacks against the police and other Government institutions across the north-eastern states of Nigeria to avenge what they considered as police brutality against its members. ${ }^{16}$ Successive conflicts between members of the sect and security forces left more than 800 people dead, including the extra-judicial killing of the leader of the sect, Mohammed Yusuf in July 2009. ${ }^{17}$

The extra-judicial execution of its leader marked a turning point in the radicalization of the leadership, hierarchy and modus operandi of the sect; a more dire and drastic leader in the person of Abubakar Shekau, who was previously Mohammed Yusuf's deputy emerged.

Since then, the sect has changed its modus operandi from using low level guerilla tactics to outright warfare by carrying out insurmountable violent and brutal attacks such as bombing of places of worship, suicide bombings, kidnapping, assassinations of individuals and groups

\footnotetext{
7 Isiramen, C. O; "Humanism and Women's Rights in Nigeria" cited in Dada, F. O; "The Justiciability and Enforceability of Women's Rights in Nigeria” (2013), 2 (1), Akungba Law Journal, 216 - 232 at 216

${ }^{8}$ Hornby op cit

${ }^{9}$ The attacks are also referred to as the 9/11 attacks wherein the twin World Trade Centre in New York and the Pentagon in Philadelphia, both in the United States were bombed by Islamic extremists affiliated with the terrorist group, Al Qaeda.

10 Council on Foreign Relations. Available at http://www.cfr.org/terrorism/global-regime-terrorism/p25729. accessed on 19th February, 2015

${ }^{11}$ Which means "People Committed to the Propagation of the Prophet's Teachings and Jihad"

12 Which means western education is forbidden. It is believed that the group took its name or was accorded its name as result of strong opposition to western education and initial withdrawal from the society. See Cook op cit at 4 .

${ }^{13}$ Mohammed, op cit at 9 - 10

14 Odomovo, A. S; "Insurgency, Counter-insurgency and Human Rights Violations in Nigeria", the Age of Human Rights Journal, 2014, pp 46 -62 at 48

${ }^{15}$ Forest, J., Confronting the Terrorism of Boko Haram in Nigeria, JSOU Press, Florida, 2012, 63

16 Odomovo, op cit at 48

${ }^{17}$ Forest, op cit at 64
} 
especially Christian minorities, prominent politicians and clerics who opposed it, across Northern Nigeria and the Federal Capital Territory of Abuja ${ }^{18}$ which the Nigerian Police could not curtail. This necessitated the deployment of the armed forces and paramilitary security outfits to the affected areas especially in North-East Nigeria.

In addition, the fruition of Boko Haram can be said to have some political undertones. Yusuf was always political and wanted an Islamic government but not in a violent way. ${ }^{19}$ According to Taiwo, the swift growth of the sect is associated with political influence and power struggle in the region. ${ }^{20}$ Yusuf formed an alliance with Ali Modu Sheriff, a one-time All Nigeria Peoples' Party (ANPP) Governor of Bornu State between 2003 - 2011, who at that time was a serving Senator of the Federal Republic of Nigeria. ${ }^{21}$ The aim of the said alliance was to use the large youth followers of Yusuf, who constitute a significant electoral bloc to vote out Mala Kachalla, who with help of Sheriff, became the Governor of Bornu State upon return to civil rule in $1999 .{ }^{22}$

However, the alliance did not come free of charge. Sheriff promised to implement strict Shariah such as criminal punishments; flogging for theft and fornication, amputation and stoning to death for adultery but reneged on this promise upon election into office. ${ }^{23}$ Although, Sheriff created a ministry of religious affairs and put a close confidante of Yusuf, in person of Buji Foi in charge of it (in return for the support rendered by Boko Haram to him during the election campaign). ${ }^{24}$ This led to a fissure in the above mentioned alliance and Yusuf began to address his sermons at Sheriff, branding him as an apostate and a turncoat. ${ }^{25}$

According to Harnischfeger, Yusuf returned from his self-imposed exile in Saudi Arabia after a rapprochement with the state, negotiated by the then Borno State deputy governor, Adamu Shettima Dibal and Sheikh Ja'afar Mahmud Adam, during the 2005 pilgrimage in Mecca, Saudi Arabia.

According to Mohammed, ${ }^{26}$ three different but relating stages can be discerned in the evolution of Boko Haram. The first stage is what can be termed as the Kanama phase (200305), when a militant jihadist group led by Muhammad Ali, a Nigerian radicalised by jihadi literature in Saudi Arabia and believed to have fought alongside the mujahideen in Afghanistan, waged war on the Nigerian state but was repelled with casualties on both sides. ${ }^{27}$

The second stage commenced with the collapse of the Kanama uprising and ended with the suppression of Boko Haram proper in July $2009 .{ }^{28}$ This period, which can be dubbed the dawah phase, was dedicated to intensive proselytisation, recruitment, indoctrination, and radicalization of its members. ${ }^{29}$ This stage involved extensive criticism of the extant secular system; debates with opposing ulama (clerics) on the propriety or otherwise of Western education, Westernization, democracy, secularism, unceasing criticism of the corruption and bad governance under the then Governor of Bornu State, Ali Modu Sheriff (2003-2011) in

\footnotetext{
${ }^{18}$ Notable examples are the bombing of the Police Headquarters and United Nations (UN) offices in June and August, 2011 respectively

${ }^{19}$ Africa Report, op cit at 9

20 Taiwo op cit at 24

${ }^{21}$ Africa Report op cit at 11 . See also Taiwo op cit at $24-25$

${ }^{22}$ Ibid

${ }^{23}$ Taiwo op cit at 25

${ }^{24}$ Harnischfeger, J, 'Boko Haram and its Muslim critics: Observations from Yobe State' in Perouse de Montclos, M. (ed) op cit, 33 - 62 at 40. It should be noted that Foi later resigned as Commissioner for Religious Affairs in 2007 due to protest. See Africa Report op cit at 12

${ }^{25}$ Taiwo op cit at 25

${ }^{26}$ Mohammed op cit at 10

${ }^{27}$ Ibid

${ }^{28}$ Ibid

${ }^{29}$ Ibid
} 
addition to the conspicuous consumption and opulence of the Western-educated elite in the midst of poverty. ${ }^{30}$

The third phase began with the 2009 suppression of the movement and the killing of its leadership in gory and barbaric form by Nigerian security agencies. ${ }^{31}$ Mohammed posits further that during this period, Boko Haram went underground, re-organised, and resurfaced in 2010 with a vengeance. ${ }^{32}$ The sect not only targeted their perceived opponents, but indiscriminately attacked security officials, politicians associated with the ruling All Nigeria Peoples Party (ANPP) government in Bornu State. ${ }^{33}$ As the military crackdown increased, the sect became desperate and more militant, thereby resorting to more desperate measures, which they had despised in the past, such as burning of school buildings, attacking telecommunications base stations, killing and kidnapping of foreigners, slaughtering as opposed to shooting of opponents, and killing of health officials at routine vaccination clinics, as well as random shooting of pupils and teachers at schools. ${ }^{34}$

The drivers of radicalization of Islamic groups include both internal and external developments ${ }^{35}$ and the deadly sect is no exception. Although the grievances of Boko Haram are largely local, its major influences have been foreign. ${ }^{36}$ Mohammed posits further that the basic message of radical Islam, whether in the Middle East, North Africa, or northern Nigeria, is the same, which primarily is that 'it is the duty of Muslims to revolt against and change apostate rulers and governments in order to help re-establish a proper Islamic state. ${ }^{37} \mathrm{He}$ concluded that the main differences among radical groups are in the methods and not the ideals. $^{38}$

\section{THE LEGAL FRAMEWORK FOR THE PROTECTION OF THE FEMALE GENDER IN NIGERIA}

Though Nigeria has acceded to and ratified various international instruments on the protection of the female gender, it is yet to domesticate most of them. The Nigerian Constitution ${ }^{39}$ remains the grundnorm for the protection of the rights of the female gender in the country. Attempt will now be made to highlight the various instruments. Various international and regional instruments that are germane to the rights of the female gender that Nigeria has ratified include; Universal Declaration of Human Rights (UDHR), International Covenant on Civil and Political Rights (ICCPR), Optional Protocol to the ICCPR concerning Individual Petition, International Covenant on Economic, Social and Cultural Rights (ICESCR), Convention against Torture and other Cruel, Inhuman or Degrading Treatment or Punishment (CAT), Convention on the Elimination of all Forms of Discrimination against Women (CEDAW), Geneva Convention relative to the Protection of Civilian Persons in Time of War, African Charter on Human and Peoples' Rights, the Beijing Declaration, the Vienna Declaration and Programme of Action amongst a host of others. These instruments oblige states to guarantee non-discrimination and equality (de jure and de facto) on the basis of gender, sex, sexual orientation and gender identity. ${ }^{40}$

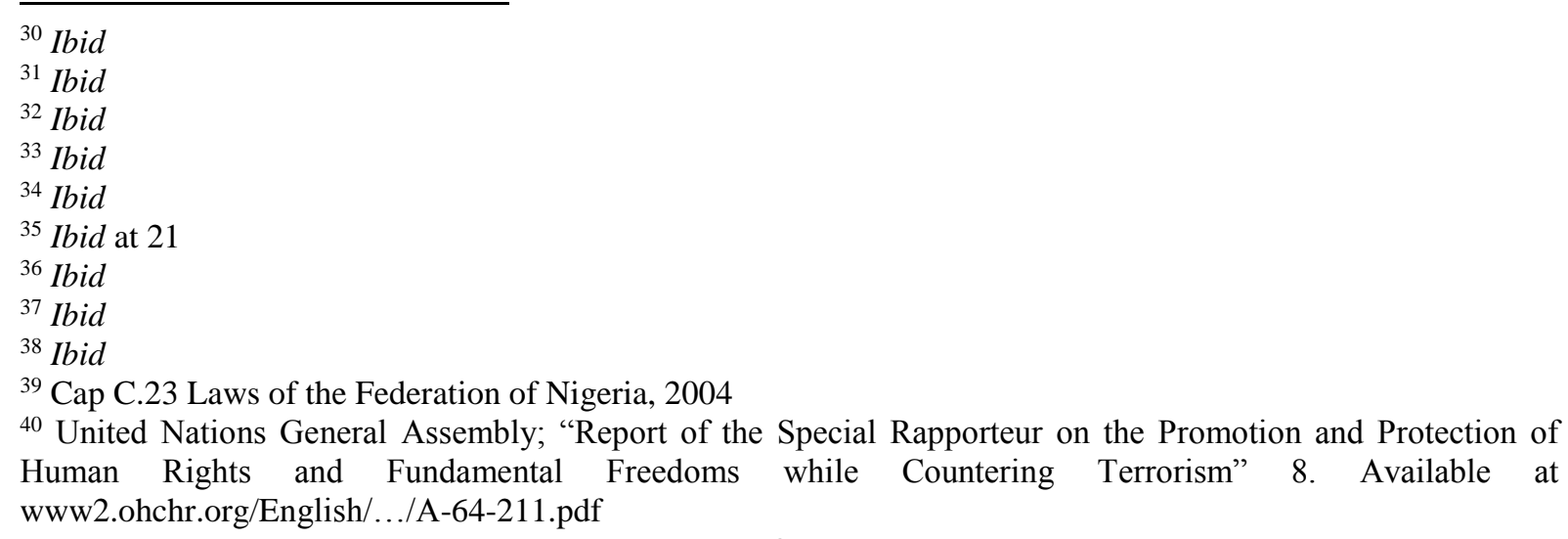


These assurances of non-discrimination and gender equality are essential in ensuring the realization of economic, social and cultural rights which are often impacted by terrorism and counter-terrorism operations. ${ }^{41}$

These instruments fall under four general categories. ${ }^{42}$ The first category consists of the comprehensive International Covenants on Civil and Political Rights and on Economic, Social and Cultural Rights, (ICCPR and ICESCR). ${ }^{43}$ The second category consist of comprehensive regional conventions such as the African Charter on Human and People's Rights, 1981. The third category consists of conventions dealing with specific wrongs such as genocide, racial discrimination or torture. While the fourth category deals with conventions related to the protection of particular set of people such as women and children. The relevance of some of these instruments will now be considered herein after -

\subsubsection{The International Covenant on Civil and Political Rights (ICCPR)}

This instrument governs fundamental rights such as; right to life, ${ }^{44}$ right to dignity of human person, ${ }^{45}$ right to liberty and security, ${ }^{46}$ and the prohibition of propaganda of war and of incitement to national, racial or religious hatred. ${ }^{47}$

Consequent upon the foregoing, every citizen of Nigeria, has a right to life and he or she shall not be intentionally deprived of this inherent right unless in the execution of the sentence of a court in respect of a criminal offence of which he or she has been found guilty. Furthermore, every citizen is entitled to respect for the dignity of his person. Therefore, he or she cannot be subjected to inhuman treatment. This is not the scenario in the Boko Haram insurgency. Female victims of the various attacks launched by the deadly sect were deprived of their lives without no just cause. It is pertinent to state that by virtue of this instrument, Nigeria is under compulsion to ensure and protect these rights without any distinction whether as a result of race, color, sex, language, religion, political or other opinion, national or social origin, property, birth or other status. ${ }^{48}$

\section{(ICESCR)}

\subsubsection{International Covenant on Economic, Social and Cultural Rights}

This covenant was promulgated in accordance with the principles proclaimed in the Charter of the United Nations, recognition of the inherent dignity and of the equal and inalienable rights of all members of the human family based on the foundation of freedom, justice and peace in the World ${ }^{49}$ It was also promulgated in accordance with the Universal Declaration of Human Rights (UDHR) and in recognition of the ideals of free human beings enjoying freedom from fear and want, which can only be achieved if conditions are created whereby everyone may enjoy his economic, social and cultural rights, as well as his civil and political rights. ${ }^{50}$

\footnotetext{
${ }^{41}$ Ibid at $8-9$

${ }^{42}$ Brownlie, I, Principles of Public International Law (6 $6^{\text {th }}$ Ed, New York: Oxford University Press, 2003) p.536

${ }^{43}$ These covenants were unanimously accepted by the General Assembly of the UNO in 1966 but came into force in 1976

${ }^{44}$ Article 6 of the International Covenant on Civil and Political Rights (ICCPR) 1966 (Entry into force in 1976). This right is also guaranteed in the constitutions of many Nations. For examples, see Constitution of the Federal Republic of Nigeria 1999 s. 33 and Constitution of the Republic of South Africa, 1996 s. 11

${ }^{45}$ Article 7 of the ICCPR. This right is also guaranteed in the constitutions of many Nations. For examples, see Section 34 of the Constitution of the Federal Republic of Nigeria 1999

${ }^{46}$ Article 9 of the ICCPR. This right is also guaranteed in the constitutions of many Nations. For examples, see Section 35 of the Constitution of the Federal Republic of Nigeria, 1999

${ }^{47}$ Article 20 of the ICCPR

${ }^{48}$ Article 2 of the ICCPR

${ }^{49}$ Preamble to the International Covenant on Economic, Social and Cultural Rights (ICESR)1966 (Entry into force in 1976)

${ }^{50}$ Preamble to the ICESR
} 
This covenant guarantees the right to work by all. ${ }^{51}$ Furthermore, it guarantees adequate standard of living rights such as rights to food ${ }^{52}$, health ${ }^{53}$ and shelter. ${ }^{54}$

\subsubsection{Convention on the Elimination of all Forms of Discrimination against Women (CEDAW)}

This convention was adopted in 1979 and can be said to be the principal instrument for the protection of women at the international plane. It enjoins State parties to prohibit discrimination against women by embodying the principle of the equality of men and women in their national constitutions or other appropriate legislation ${ }^{55}$ and adopting appropriate legislative and other measures prohibiting all discrimination against women, including sanctions where appropriate. ${ }^{56}$ It charges States to establish legal protection of the rights of women on an equal basis with men and to ensure through competent national tribunals and other public institutions the effective protection of women against any act of discrimination ${ }^{57}$ amongst others. This instrument governs fundamental rights such as; right to education, ${ }^{58}$ employment rights, ${ }^{59}$ and equal access to healthcare. ${ }^{60}$ The convention places on States to take into account problems faced by rural women and the significant roles played by such women in the economic survival of their families. ${ }^{61}$

\subsubsection{Convention against Torture and other Cruel, Inhuman or Degrading Treatment or Punishment (CAT)}

This convention guarantees the right of both men and women not to be subjected to torture and other cruel, inhuman or degrading treatment or punishment. Article 4 of the convention charges State parties to criminalize torture with appropriate penalties within their respective jurisdictions. States Parties are also enjoined to afford one another the greatest measure of assistance in connection with criminal proceedings brought in respect of any of the offences referred to in article 4, including the supply of all evidence that are necessary for such proceedings at their disposal. ${ }^{62}$

The convention further mandate each state party to ensure that education and information regarding the prohibition against torture are fully included in the training of law enforcement personnel, civil or military, medical personnel, public officials and other persons who may be involved in the custody, interrogation or treatment of any individual subjected to any form of arrest, detention or imprisonment. ${ }^{63}$ The convention also obligate states to ensure that, its competent authorities proceed to a prompt and impartial investigation, wherever there is reasonable ground to believe that an act of torture has been committed in any territory under its jurisdiction. ${ }^{64}$ Under the convention, any individual who alleges he or she has been subjected to torture has the right to complain and have his or her case promptly and impartially examined by competent authorities. ${ }^{65}$

States must take steps to ensure that the complainant and witnesses are protected against all ill-treatment or intimidation as a consequence of the complaint or any evidence given. ${ }^{66}$ Each State Party must also ensure in its legal system that the victim of an act of torture

\footnotetext{
51 Article 6 (1) to the ICESR

52 Article 11

53 Article 12

54 Article 11

${ }^{55}$ Article 2 (a)

56 Article 2 (b)

${ }^{57}$ Article 2 (c)

58 Article 10

${ }^{59}$ Article 11

${ }^{60}$ Article 12

${ }^{61}$ Article 14

${ }^{62}$ Article 9 (1)

${ }^{63}$ Article 10

${ }^{64}$ Article 12

65 Article 13

${ }^{66}$ Ibid
} 
obtains redress and has an enforceable right to fair and adequate compensation, including the means for full rehabilitation as possible. In the event of the death of the victim as a result of an act of torture, his dependants shall be entitled to compensation. ${ }^{67}$

Article 16 directs Each State Party to prevent in any territory under its jurisdiction other acts of cruel, inhuman or degrading treatment or punishment which do not amount to torture, when such acts are committed by or at the instigation of or with the consent or acquiescence of a public official or other person acting in an official capacity. ${ }^{68}$

\subsubsection{Geneva Convention IV and Additional Protocols I and II Relative to the Protection of Civilian Persons in Time of War}

The Geneva Conventions which were adopted before 1949 were in respect of Combatants and not Civilians. ${ }^{69}$ Although some provisions in respect of the protection of populations against the consequences of war and their protection in occupied territories are contained in the Regulations concerning the laws and customs of war on land, annexed to the Hague Convention of 1899 and $1907 .{ }^{70}$ This provision became inadequate during World Wars I and II because of the dangers emanating from air warfare and of the problems relating to the treatment of civilians in enemy territories and in occupied territories. ${ }^{71}$ Consequently, the Geneva Convention IV was introduced by the International Committee of the Red Cross (ICRC) in order to improve the situation of war victims. ${ }^{72}$

Two Additional Protocols were adopted in 1977, to extend and strengthen the protections provided in the Geneva Conventions. ${ }^{73}$ These treaties form part of the law of armed conflict and contain certain provisions that apply specifically to women. ${ }^{74}$

Examples of these provisions includes but not limited to the protection of women against any attack on their honour, in particular against rape, enforced prostitution, or any form of indecent assault. ${ }^{75}$

\subsubsection{African Charter on Human and Peoples' Rights}

The African Charter on Human and Peoples' Rights (ACHPR) also known as the Banjul Charter is an international human rights instruments for the protection of human rights on the African Continent. ${ }^{76}$ The oversight and interpretation of the Charter is within the purview of the African Commission on Human and Peoples' Rights, which was established in 1987, with headquarters now in Banjul, The Gambia. ${ }^{77}$

Article 2 of the Charter enshrines the principle of non-discrimination on the grounds of race, ethnic group, colour, sex, language, religion, political or any other opinion, national and social origin, fortune, birth or other status. While Article 18 calls on all States Parties to

\footnotetext{
${ }^{67}$ Article 14

${ }^{68}$ Article 16

${ }^{69}$ International Committee of the Red Cross (ICRC), 'Treaties, States Parties and Commentaries'; Convention (IV) relative to the protection of Civilian Persons in Time of War, Geneva, 12 August, 1949. Available at https://www.icrc.org/ihl/INTRO/380. Accessed on 8th April, 2016

${ }^{70}$ Ibid

71 Ibid

72 Department of Economic and Social Affairs, Division for the advancement of Women, United Nations; 'Sexual Violence and Armed Conflict: United Nations Response' Published to Promote the Goals of the Beijing Declaration and the Platform of Action, April 1998. Available at www.un.org/womenwatch/daw/publication....cover.pdf. Accessed on $7^{\text {th }}$ April, 2016

${ }^{73}$ Ibid

${ }^{74}$ Ibid

${ }^{75}$ Article 27 of the Geneva Convention IV, 1949. Similar provisions are contained in Articles 76 (1) and Article 4 (2) (e) of the Additional Protocols I and II of 1977 respectively.

76 African Commission on Human and Peoples' Rights, 'African Charter on Human and People's Rights' available at http://www.achpr.org/instruments/achpr/ accessed on $7^{\text {th }}$ April, 2016

${ }^{77}$ Ibid
} 
eliminate every discrimination against women and to ensure the protection of the rights of women as stipulated in international declarations and conventions. ${ }^{78}$

\subsubsection{Protocol to the African Charter on Human and Peoples' Rights on the Rights of Women in Africa}

This protocol is also known as the Maputo Protocol. ${ }^{79}$ State parties to the protocol in furtherance to the provisions of Article $66^{80}$ of the African Charter on Human and Peoples' Rights and in reaffirming the principle of gender equality alongside recognizing the crucial role of women in the preservation of African values based on the principles of equality, peace, freedom, dignity, justice, solidarity and democracy agreed to this protocol. ${ }^{81}$

The protocol amongst other things guarantees elimination of all discrimination against women, ${ }^{82}$ elimination of harmful practices, ${ }^{83}$ and women rights such as dignity, ${ }^{84}$ life, integrity and security of person, ${ }^{85}$ and equality in marriage. ${ }^{86}$ Provisions on access to justice and equal protection before the Law, ${ }^{87}$ right to participate in the political and decision making process, ${ }^{88}$ protection of women in armed conflicts, ${ }^{89}$ right to education and training ${ }^{90}$ and economic and social rights ${ }^{91}$ are enshrined in the Protocol.

\subsubsection{The Beijing Declaration and Programme of Action}

The Beijing Declaration and Programme of Action is the outcome of the Fourth World Conference on Women: Action for Equality, Development and Peace organized by the United Nations from the $4^{\text {th }}-5^{\text {th }}$ September, 1995 in Beijing, China.

Governments are mandated to intensify efforts to ensure equal enjoyment of all human rights and fundamental freedoms for all women and girls who face multiple barriers to their empowerment and advancement because of such factors as their race, age, language, ethnicity, culture, religion, or disability, or because they are indigenous people. ${ }^{92}$

Paragraph 232(a) of the Declaration obliges Governments to give priority to promoting and protecting the full and equal enjoyment by women and men of all human rights and fundamental freedoms without distinction of any kind as to race, colour, sex, language, religion, political or other opinions, national or social origins, property, birth or other status.

While, Paragraph 133 of the Declaration states that 'violation of human rights in situations of armed conflict and military occupation are violations of the fundamental principles of international human rights and humanitarian law as embodied in international human rights instruments in the Geneva Conventions of 1949 and the Additional Protocols thereto'

\footnotetext{
${ }^{78}$ Article 18 (3)

${ }^{79}$ It was adopted by the African Union on $11^{\text {th }}$ July, 2003 at its second summit in Maputo, Mozambique and came into force on $25^{\text {th }}$ November, 2005, after the ratification of the requisite 15 member nations of the Union.

${ }^{80}$ This Article provides for special protocols or agreements, if necessary, to supplement the provisions of the African Charter

${ }^{81}$ Preamble to the Protocol to the African Charter on Human and Peoples' Rights on the Rights of Women in Africa. Available at www.achpr.org/files/instruments/women....achpr_instr_proto_women_eng.pdf . accessed on 19th March, 2016

${ }^{82}$ Article 2

${ }^{83}$ Article 5

${ }^{84}$ Article 3

${ }^{85}$ Article 4

${ }^{86}$ Article 6

${ }^{87}$ Article 8

${ }^{88}$ Article 9

${ }^{89}$ Article 11

${ }^{90}$ Article 12

91 Article 13

92 Paragraph 32 of the Beijing Declaration and the Platform for Action, Fourth World Conference on Women, Beijing, China, September 4-15 1995, U.N. Doc. A/CONF.177/20 (1996). Available at www.beijing20.unwomen.org/.../.../BeijingDeclarationAndPlatformForAction-en.pdf. accessed on $19^{\text {th }}$ January, 2016
} 


\subsubsection{The Vienna Declaration and Programme of Action}

The Vienna Declaration and Programme of Action is the outcome of the 1993 UN World Conference on Human Rights held in Vienna. Of particular significance was the recognition that violence against women, such as domestic abuse, mutilation, burning and rape, is a human rights issue..$^{93}$ Previously, these acts had been regarded as private matters, and therefore not appropriate for government or international action. ${ }^{94}$ Even the Convention on the Elimination of all Forms of Discrimination against Women (Women's Convention), adopted in 1979, has no specific provision on violence against women. ${ }^{95}$

The declaration provides that 'the human rights of women and of the girl-child are an inalienable, integral and indivisible part of universal human rights and that the full and equal participation of women in political, civil, economic, social and cultural life, at the national, regional and international levels, and the eradication of all forms of discrimination on grounds of sex are priority objectives of the international community. ${ }^{96}$

Article 38 of the Declaration states that "Violations of the human rights of women in situations of armed conflict are violations of the fundamental principles of international human rights and humanitarian law. All violations of this kind, including in particular murder, systematic rape, sexual slavery, and forced pregnancy, require a particularly effective response."

\subsubsection{Declaration on the Protection of Women and Children in Emergency and Armed Conflict}

This declaration was proclaimed by General Assembly resolution 3318 (XXIX) of 14 December 1974 upon the recommendation of the Economic and Social Council contained in its resolution 1861 (LVI) of 16 May 1974. This declaration is as a result of women and children suffering victimization, inhuman acts and serious harm during armed conflict due to suppression, aggression, colonialism, racism, alien domination and foreign subjugation. ${ }^{97}$

Article 1 of the declaration prohibits attacks and bombing of civilian populations, while Article 2 prohibits the use of chemical and biological weapons on civilian populations.

Under this Declaration, states are duty-bound to abide by their obligations under the Geneva Protocol of 1925 and Convention of $1949 .{ }^{98}$ The declaration criminalizes all forms of repression and cruel and inhuman treatment of women and children, including imprisonment, torture, shooting, mass arrests, collective punishment, destruction of dwellings and forcible eviction, committed by belligerents in the course of military operations or in occupied territories. ${ }^{99}$

States involved in armed conflicts, military operations in foreign territories or military operations in territories still under colonial domination are mandated to make all efforts to spare women and children from the ravages of war by ensuring that all necessary steps are taken to ensure the prohibition of measures such as persecution, torture, punitive measures,

\footnotetext{
${ }^{93}$ Department of Economic and Social Affairs, Division for the advancement of Women, United Nations; 'Sexual Violence and Armed Conflict: United Nations Response' Published to Promote the Goals of the Beijing Declaration and the Platform of Action, April 1998. Available at www.un.org/womenwatch/daw/publication....cover.pdf. Accessed on $7^{\text {th }}$ April, 2016

${ }^{94}$ Ibid

95 Ibid

${ }^{96}$ Paragraph 18 of the Vienna Declaration and Programme of Action, World Conference on Human Rights, Vienna, Austria, June 14-25, 1993, U.N. Doc. A/CONF.157/23 (1993). Available at http://www.ohchr.org/EN/ProfessionalInterest/Pages/Vienna.aspx

${ }^{97}$ Preamble to the Declaration on the Protection of Women and Children in Emergency and Armed Conflict. Available at http://www.ohchr.org/EN/ProfessionalInterest/Pages/ProtectionOfWomenAndChildren.aspx. accessed on 20th March, 2016

98 Article 3

${ }^{99}$ Article 5
} 
degrading treatment and violence, particularly against that part of the civilian population that consists of women and children. ${ }^{100}$

In conclusion, the Declaration provides that women and children who found themselves in emergency or conflict situations should not be deprived of their inalienable and inherent rights such as shelter, food and medical aid, in accordance with the provisions of the Universal Declaration of Human Rights, the International Covenant on Civil and Political Rights, the International Covenant on Economic, Social and Cultural Rights, the Declaration of the Rights of the Child or other instruments of international law. ${ }^{101}$

\section{IMPLICATIONS OF THE INSURGENCY AND COUNTER-INSURGENCY ON THE FEMALE GENDER}

Hitherto, the female gender has suffered gender discrimination and violence stemming from political, cultural, ${ }^{102}$ social, ${ }^{103}$ economic ${ }^{104}$ and religious ${ }^{105}$ reasons in Nigeria in general and in the insurgency-torn areas in particular, which maybe as a result of conception that the major role of a woman is that of child-bearer, child-raiser and home-maker. ${ }^{106}$ Majority of the female gender in Northern Nigeria are vulnerable and live in poverty. ${ }^{107}$ The insurgency has also compounded their problems in that they suffer from ill-treatment and abuse. This

${ }^{100}$ Article 4
${ }^{101}$ Article 6
${ }^{102}$ A trite example is widowhood practices especially among the Ibos of South-East Nigeria, whereby a widow cannot inherit the personal or real estate of her husband. See the case of Nezianya $v$. Okagbue \& Ors. (1963) 1 $\boldsymbol{A L L}$ NLR 352. This is also applicable among the Yorubas of South-West Nigeria, especially in cases where the husband dies intestate. See the cases of Osilaja v. Osilaja (1972) 10 SC 126. Other harmful cultural practices include the beating of wives, which is permitted as a form of discipline. See section 551 (1) (d) of the Penal Code Act, (Cap P.3), Laws of the Federation of Nigeria, 2004

${ }^{103}$ Women are not permitted to stand surety for bail. Furthermore women are denied tax relief for their dependants unlike their male counterpart, who enjoy tax reliefs by virtue of the married man allowance. Another trite issue is that of Citizenship. Section 26 (2) (a) of the Nigerian constitution denies a woman the right to confer citizenship status on her foreign husband but grants such right to a foreign woman married to a Nigerian man. In addition, the Section 353 of the Criminal Code Act (applicable to Southern Nigeria) provides for the harsher offence of felony and punishment of three (3) years imprisonment for assault committed against a Man by a Woman. While, Section 360 of the same Code, provides for a lesser offence of misdemeanor and punishment of two (2) years for assault committed against a Woman by a Man.

${ }^{104}$ By virtue of sections 55 and 56 of the Labour Act (Cap L.1, Laws of the Federation of Nigeria, 2004), women are excluded from underground work and are restricted from doing certain jobs such as night work in any agricultural undertaking, public or private industrial undertaking or any branch thereof. In addition, Sections 121 - 126 of the Nigeria Police Regulations Act (Cap P.19, Laws of the Federation of Nigeria, 2004), regulates the affairs of women in ways other than that of men. Under the regulations, Women Police Officers are employed for duties that are concerned with women and children only. Married women are not allowed to enlist in the Police Force. Furthermore, a woman in the Nigerian Police must seek the permission of the Commissioner of Police in her area of service before she can marry upon satisfying the conditions precedent of having spent two (2) years in the police and furnishing the police with the particulars of the fiancé, who must be investigated and cleared.

In concluding on these regulations, an unmarried pregnant police officer shall be discharged from the force, while a married woman cannot be granted any special privileges because she is married and shall be subject to postings and transfers as if unmarried. These provisions are discriminatory in that they show the notion that women are weaker to men and an affront to the right of a woman to marry and raise a family as enshrined in section 37 of the Constitution of the Federal Republic of Nigeria, 1999 (as amended).

${ }^{105}$ For example under Islamic Law (Shariah), a woman cannot be appointed as a Judge (Kadi of the Shariah Court of Appeal). Furthermore, in cases of adultery, a man can swear his innocence by denying having had sexual intercourse with a woman and be discharged and acquitted because such statement on oath is deemed as sufficient proof of innocence unless same is rebutted by four independent and trustworthy eye-witnesses. See the case of Safiyatu Hussain Titudu v. Attorney-General of Sokoto State (2008) vol. 1 WHRC 309

106 Akintola, S. O \& Taiwo ,E. A., Nigerian Woman and Her Child: The Remaining Challenges (Demyaxs Books, Ibadan, 2004) 3

${ }^{107}$ Cook op cit at 5 
section will examine the various human rights abuses perpetrated on the female gender due to the Boko Haram insurgency.

\subsection{Killing of Members of the Female Gender}

The Boko Haram insurgency and counter-insurgency is destroying the lives of females in Nigeria. Nigerian females have been on the receiving end of the brunt of the insurgency as a result of increasing feminisation of terror by Boko Haram in two paradoxical ways vide the use of young girls as both the victims and vanguards of terror. ${ }^{108}$ As victims of terror, in the form of abductees, while as vanguards of terror, females are used as bombers in carrying out suicidal attacks. ${ }^{109}$ According to Onuoha and George, the bulk of suicide bombings have been carried out by abducted females who hitherto were recruiters and couriers of arms, foodstuffs and money. ${ }^{110}$

This is an affront on the right to life of female folks. The right to life can be said to be the supreme right and the foundation of all rights. This right is guaranteed under Section 33 (1) of the constitution of the Federal Republic of Nigeria, 1999 as amended. ${ }^{111}$ Every person whether citizens of Nigeria or not, is entitled to this right which can only be deprived as provided for by the constitution itself. ${ }^{112}$

The first female suicide bomb attack occurred on $8^{\text {th }}$ June 2014 , at the 301 Battalion barracks of Nigerian Army in Gombe, Gombe State, which resulted in the death of the girl, who carried the bomb in her hijab and a soldier. ${ }^{113}$ This attack was followed by the bombing of an energy depot in Lagos by a female attacker on the $25^{\text {th }}$ of that same month. ${ }^{114}$ The nefarious sect continues to use girls as young as eleven years of age as human bombs to wreck havocs and carry out barbaric acts in other cities such as Kano, Yola and Maiduguri. ${ }^{115}$ The deadly sect has extra-judicially executed women and children especially those of the Christian faith. ${ }^{116}$ A number of women and girls who were forced to marry Boko Haram fighters were killed when the group was forced to retreat by the joint forces, reportedly so that they would not remarry "infidels" or provide information to regional forces. ${ }^{117}$ These acts are gross violations of the provisions on right to life as guaranteed under Section 33 (1) of the Nigerian Constitution and Article 6 of the ICCPR.

\footnotetext{
108 Onuoha, F. C \& George T. A; "Boko Haram's Use of Female Suicide Bombing in Nigeria” (2015); Al Jazeera Center for Studies. 2. Available at www.studies.aljazeera.net./.../...20153189319985734Boko-HaramsFemale.pdf. Accessed on $7^{\text {th }}$ November 2015

111 Section 33 (1) of the Constitution of the Federal Republic of Nigeria 1999 provides that "every person has a right to life and no one shall be deprived intentionally of his life, save in execution of a sentence of a court in respect of a criminal offence of which he has been found guilty"

This right is also guaranteed under International instruments such as Article 6 of the International Covenant on Civil and Political Rights (ICCPR) to which Nigeria has acceded to. In addittion, Article 4 of the African Charter provides that "Human beings are inviolable. Every human being shall be entitled to respect for his life and integrity of his person. No one maybe arbitrarily deprived of this right"

112 Permissible limitations on the right to life are provided for in Section 33 (2)

${ }^{113}$ Onuoha, F. C \& George T. A op cit at 4

114 Ibid

115 Boko Haram; Young Female Suicide Bombers kill 15 in Nigeria Market Attack. Available at http;//www.theguardian.com/world/2015nov/18/young-female-suicide-bombers-kill-15-in-nigeria-market-attack. Accessed on $19^{\text {th }}$ January, 2016

116 Barkindo et al op cit at 19

117 Office of the High Commissioner on Human Rights (OCHR); Report of the United Nations High Commissioner on Human Rights on Violations and Abuses Committed by Boko Haram and the Impact on Human Rights in the Affected Countries. Available at www.ochr.org/.../HRC/.../A-HRC-30-67_en.doc. accessed on 7th November, 2015
} 


\subsection{Abduction, Rape, Sexual Violence, Sexual Slavery, Forced Marriages and Breaches of the right to freedom of thought, conscience and religion}

Boko Haram abducts women and girls during raids on towns and villages in NorthEast Nigeria and detained them in Boko Haram's camps and towns under their control. A trite example is the abduction of 276 female students of Government Secondary School, Chibok, Bornu State from their hostel on $14^{\text {th }}$ April, 2014 into the Sambisa forest head-quarters of the sect. ${ }^{118}$ It is worthy to note that the Nigerian government successful negotiated the release of 103 of the abducted Chibok school girls in exchange for the release of some top Boko Haram commanders. ${ }^{119}$

According to Amnesty International, Boko Haram routinely rounds up women and girls and detain them in large houses under armed guard. ${ }^{120}$ Women and girls that have escaped from Boko Haram reported to Amnesty International that, many were forced to marry Boko Haram members. ${ }^{121}$ In a video released on 13 May 2013, the Boko Haram leader, Abubakar Shekau announced that Boko Haram had abducted women and children in response to the arrest of the wives and children of its members. The sect has singled out unmarried women for abduction, forcing them into marriage with its members, claiming that they are religiously obliged to be married. ${ }^{122}$ In camps and territories controlled by Boko Haram, women were raped by their new husbands or secretly in the bush by members of the sect. ${ }^{123}$

Women previously detained in Boko Haram camps also informed Amnesty International that Boko Haram had given them religious education classes on Islamic prayers and practices, ordered Christian girls to convert to Islam and to follow Boko Haram's interpretation. $^{124}$

According to the Office of the High Commissioner on Human Rights (OCHR), discussions with psychosocial counsellors in northeast Nigeria confirmed widespread sexual violence against women and girls held by Boko Haram. One counsellor reported that a girl who managed to escape narrated how Boko Haram fighters would sexually abuse her, telling her 'you are the kind of girls we like'. ${ }^{125}$ Another interviewee told OHCHR that she witnessed the rape of girls as young as $15 .^{126}$

OHCHR also documented cases of rape emanating from forced marriages to Boko Haram members, during an attack on Bama, Borno state, Nigeria, in September 2014. ${ }^{127}$ OHCHR was informed about a Nigerian refugee woman in Niger, who was abducted in Damasak, Borno state, on 28 November 2014, and raped by 40 men. ${ }^{128}$ A 14-year-old girl told OHCHR she was raped when Boko Haram attacked Damasak, in November 2014, and that, after killing the men and boys, they took the women and children to a house and selected

\footnotetext{
118 Just as the 276 Chibok Girls were abducted by the Boko Haram Sect, hundreds of yazidi girls were abducted by the deadly terrorist group, Islamic State in Iraq and Syria (ISIS) under similar circumstances. Some of the Yazidi girls have been rescued with the help of western superpowers backed International coalition forces, form the Sinjar Mountains, where some of them fled when ISIS invaded their homes. The Iraqi episode can be said to have ended well as some of the yazidi girls are being rescued and rehabilitated vide training in photo journalism. See further Onyibe, M, 'Terrorism: Comparing Chibok and Yazidi Girls (1)' The Punch Newspaper, Monady, November 2, 2015, 24.

119 The Vanguard Newspaper Editorial, 'Return of 82 more Chibok Girls' (Editorial The Vanguard, May 12, 2017) Available at www.vanguardngr.com/2017/05/return-82-chibok-girls/. accessed on 13th August, 2017.

${ }^{120}$ Amnesty International; "Our job is to shoot, slaughter and kill”, Boko Haram's reign of terror in North-East Nigeria, April 2015, 24 available at www.amnesty.org, accessed on $9^{\text {th }}$ September, 2015

${ }^{121}$ Ibid

${ }^{122}$ Ibid at 63

${ }^{123}$ Ibid at 64

${ }^{124}$ Ibid

125 Office of the High Commissioner on Human Rights (OCHR) op cit

${ }^{126}$ Ibid

${ }^{127}$ Ibid

${ }^{128}$ Ibid
} 
some 40 girls to marry their fighters. She was forcefully married and raped three times before escaping, during a "wedding", with three other girls. ${ }^{129}$

The Borno Elders and Leaders of Thought pressure group accused the Military JTF of killing innocent young men and raping of married women and young girls though the Military denied the allegations. ${ }^{130}$

These violations are an affront to Paragraph 133 of the Beijing Declaration, ${ }^{131}$ right to dignity of person as enshrined in Section 34 of the Nigerian Constitution and Article 8 of the ICCPR respectively. Furthermore, forced marriages are gross violations of the provisions of Article 23 (2) and (3) of the ICCPR. ${ }^{132}$ Amnesty International also indicated in its reports that it received information that some abducted girls under the age of fifteen were forced to take active part both in battle and in executions. ${ }^{133}$ This act constitutes a war crime and is a flagrant abuse of the rights of the child. The Optional Protocol to the Convention on the Rights of the Child, 1989, which borders on the involvement of children in armed conflict, prohibits armed groups such as the Boko Haram sect from recruiting or using in hostilities persons under the age of 18 years. ${ }^{134}$ The Nigerian Child Rights Act also prohibits the use of children in any military operation or hostilities or other criminal activities. ${ }^{135}$ The issue of forced religion is a gross violation of the right to freedom of religion as enshrined in Section 38 of the Nigerian constitution. ${ }^{136}$ This provision of the constitution is very important in a multi-religious country like Nigeria, where various religious beliefs and practices must be accorded equal opportunity. Thus, no one must be punished for entertaining or professing any religious belief or disbelief. ${ }^{137}$

It is pertinent to state that armed conflicts such as the Boko Haram insurgency do have a devastating and harsh impact on women and girls. Women and girls suffer violations such as rape, forced prostitution, sexual slavery and forced impregnation. ${ }^{138}$

\footnotetext{
129 Ibid

${ }^{130}$ Daily Trust, 15 July 2011 cited in Mohammed op cit at 27

131 The Beijing Declaration and Platform for Action of the Fourth World Conference on Women, 1995. Available at www.beijing20.unwomen.org/.../.../BeijingDeclarationAndPlatformForAction-en.pdf. accessed on $19^{\text {th }}$ January, 2016

132 Article 23 (2) and (3) of the ICCPR provides thus;

(2) The right of men and women of marriageable age to marry and to found a family shall be recognized.

(3) No marriage shall be entered into without the free and full consent of the intending spouses.

${ }^{133}$ Amnesty International, "Our job is to shoot, slaughter and kill”, Boko Haram's reign of terror in North-East Nigeria op cit at 24

${ }^{134}$ Article 4 (1) Optional Protocol to the Convention on the Rights of the Child on the involvement of children in armed conflict

${ }^{135}$ Sections 34 and 26 respectively, of the Child Rights Act, Cap C50, Laws of the Federation of Nigeria,2004

${ }^{136}$ Sub-sections (1) and (2) of this section provides that:
}

(1) Every person shall be entitled to freedom of thought, conscience and religion, including freedom to change his religion or belief, and freedom (either alone or in community with others, and in public or in private) to manifest and propagate his religion or belief in worship, teaching, practice and observance.

(2) No person attending any place of education shall be required to receive religious instruction or to take part in or attend any religious ceremony or observance if such instruction ceremony or observance relates to a religion other than his own, or religion not approved by his parent or guardian.

137 St. Emmanuel, S. A; "Interplay of Humanitarian Law and Human Rights Law in Boko Haram Insurgency" (2015) 3 (1) Akungba Law Journal, 213 - 238 at 230

${ }^{138}$ Lindsey, C, 'The Impact of Armed Conflict on Women', in: Durham/Gard, Listening to Silence: Women and War, 2005, 21 cited in European Center for Constitutional and Human Rights (ECCHR),

"Alternative report on the implementation of the UN Convention on the Elimination of Discrimination against Women (CEDAW) - Sri Lanka' "Women and Armed Conflict" Berlin/Geneva, January 2010. Available at www2.ohchr.org/English/bodies/cedaw/ECCHR_Sri_Lanka_for_the_session_CEDAW48.pdf accessed on $7^{\text {th }}$ April, 2016 


\section{Olugbenga Oke-Samuel, S. Ayooluwa St. Emmanuel}

\subsection{Displacement and separation from family Members}

As a result of the insurgency, many women and girls have fled their ancestral homes, thereby losing their adequate standard of living rights such as health, shelter, water and sanitation. As a result of displacement, many young girls of school age are out of school. Increase in Internally Displaced Persons has resulted in food shortages and the use of children especially the girl child to look for food, thus making them vulnerable to sexual abuse. Furthermore, there are protection issues such as "insecurity, tensions amongst residents, and between them and host communities, and sexual and gender-based violence" across Internally Displaced Persons' Camps in the Country. ${ }^{139}$ Displacement also causes separation between family members while fleeing.

\subsection{Economic, Social and Cultural Rights}

The insurgency has violated the economic, social and cultural rights of women and the girl child in that, provisions of social services are interrupted. Schools, Hospitals and Government buildings have been burnt by the insurgents during raids. Majority of the female children in North-East Nigeria are out of school because of the ban on western education by the sect, fear of abduction and rape, no learning facility due to burnt and destroyed schools. This is a gross violation of the right to education as provided for under international ${ }^{140}$ and regional instruments ${ }^{141}$ ratified by the Country.

Another right of the female gender violated under this category of rights is the right to work. The right to work signifies means of livelihood and breach of this right amount to loss of livelihood. The North-East part of the country where the deadly sect operates is more of an agrarian society, with many of the female folks living on farming. The fear of insurgency and counter-insurgency has made many women to flee their villages and thus not able to cultivate their farmlands. While the shops of those who are into trading especially Christian women have been looted and destroyed by the sect during raids, ${ }^{142}$ thereby reducing income and economic growth and increasing poverty among the affected populace.

\subsection{Arbitrary Arrest, Unlawful Detention and Arbitrary Deprivation of Liberty}

In towns overran by the sect, women were imprisoned in large houses and not permitted to leave. ${ }^{143}$ Nigerian soldiers also committed abuses bordering on mass arbitrary arrest and unlawful detention. The military arbitrarily and indiscriminately carried out targeted arrests of relatives of suspected Boko Haram Members. According to Amnesty International, a senior military official informed it in confidence that the military had arrested women married to senior Boko Haram members and their children. He shared with Amnesty International a document, dated 12 March 2013, which contains a list of 17 women and girls, all apparently married to Boko Haram suspects, who were detained by troops from Operation Restore Order (ORO) III in Presidential Lodge, Damaturu in Yobe state. Eleven of them were detained with their children. The document indicates that most were arrested between September and November 2012. Two of them were girls aged 14 and $16 .{ }^{144}$ Under the Convention on the Rights of the Child, 1989, State parties have an obligation to "respect and

139 Office of the High Commissioner on Human Rights (OCHR); Report of the United Nations High Commissioner on Human Rights on Violations and Abuses Committed by Boko Haram and the Impact on Human Rights in the Affected Countries. Available at www.ochr.org/.../HRC/.../A-HRC-30-67_en.doc. accessed on 7 th November, 2015

${ }^{140}$ See Articles 26 of the Universal Declaration of Human Rights; 13 and 14 of the ICESCR; 10 of CEDAW

${ }^{141}$ See Articles 17(1) of the African Charter on Human and Peoples' Rights; 11 of the African Charter on the Rights and Welfare of the Child

142 Barkindo et al op cit at 19

${ }^{143}$ Amnesty International, "Our job is to shoot, slaughter and kill”, Boko Haram's reign of terror in North-East Nigeria op cit at 63

${ }^{144}$ Amnesty International, Stars on their Shoulders. Blood on their Hands, War Crimes committed by the Nigerian Military, June 2015, 80 - 81. A report by Amnesty International. Available at www.amnesty.org, accessed on $18^{\text {th }}$ July, 2015. 
ensure respect for rules of international humanitarian law applicable to them in armed conflicts which are relevant to the child. ${ }^{145}$ Furthermore, Amnesty International has also documented the arrest and detention of 30 women and girls. ${ }^{146}$ The vast majority of arrests carried out by the military and imprisonment on the part of the sect are entirely arbitrary. These arrests contravene the fundamental right to liberty and are clear violations of the rights of the above mentioned women and children not to be subjected to arbitrary arrest or detention, a fundamental right guaranteed under Section 35 of the Constitution of the Federal Republic of Nigeria, $1999,{ }^{147}$ the International Covenant on Civil and Political Rights (ICCPR) ${ }^{148}$ and the African Charter on Human and Peoples' Right (African Charter), which Nigeria is a signatory.

\subsection{Reproductive Rights}

Women also suffer the risk of being infected with sexually transmitted diseases (STDs) and HIV/AIDs by their abductors. For example, members of the sect, after taking control of towns regularly raped women with or without condoms despite the prevalence of HIV. ${ }^{149}$

Some women as a result of been raped by members of the sect, become pregnant with unwanted pregnancies and illegitimate children, thereby suffering rejection from family

${ }^{145}$ Article 38(1) Convention on the Rights of the Child

146 Amnesty International, Stars on their Shoulders. Blood on their Hands, War Crimes committed by the Nigerian Military op cit at 76

147 This section provides that Every person shall be entitled to his personal liberty and no person shall be deprived of such liberty save in the following cases and in accordance with a procedure permitted by law;

(a) In execution of the sentence or order of a court in respect of a criminal offence of which he has been found guilty;

(b) By reason of his failure to comply with the order of a court or in order to secure the fulfillment of any obligation imposed by law;

(c) For the purposes of bringing him before a court in the execution of the order of a court or upon reasonable suspicion of his having committed a criminal offence, or to such extent as maybe reasonably necessary to prevent his committing a criminal offence;

(d) In the case of a person who has not attained the age of eighteen years for the purpose of his education or welfare;

(e) In the case of a person suffering from infectious or contagious diseases, persons of unsound mind, person addicted to drugs or alcohol or vagrants, for the purpose of their care or treatment or the protection of the community; or

(f) For the purpose of preventing the unlawful entry of any person into Nigeria, or of effecting the expulsion, extradition or other lawful removal from Nigeria of any person or the taking of the proceedings thereto.

Provided that a person who is charged with an offence and who has been detained in lawful custody

awaiting trial shall not continue to be kept in such detention for a period longer than the maximum period of imprisonment prescribed for the offence.

Furthermore, in spite of the imperfections of the Nigerian constitution as regards the above provision, it does not empower the Military to detain individuals without reasonable suspicion and without oversight by the courts. See further, Section 23 of the Terrorism (Prevention) Act as amended in 2013.

148 Article 9 provides as follows:

1. Everyone has the right to liberty and security of person. No one shall be subjected to arbitrary arrest or detention. No one shall be deprived of his liberty except on such grounds and in accordance with such procedure as are established by law.

2. Anyone who is arrested shall be informed, at the time of arrest, of the reasons for his arrest and shall be promptly informed of any charges against him.

3. Anyone arrested or detained on a criminal charge shall be brought promptly before a judge or other officer authorized by law to exercise judicial power and shall be entitled to trial within a reasonable time or to release. It shall not be the general rule that persons awaiting trial shall be detained in custody, but release may be subject to guarantees to appear for trial, at any other stage of the judicial proceedings, and, should occasion arise, for execution of the judgement.

${ }^{149}$ Amnesty International, "Our job is to shoot, slaughter and kill”, Boko Haram's reign of terror in North-East Nigeria op cit at 64 
members and becoming the laughing stock of the society. About 150 women from the Dalori camp, which opened in April 2015 and hosts Internally Displaced Persons from Bama, had given birth after they escaped from captivity. ${ }^{150}$

According to OHCHR, Numerous women and girls gave birth or miscarried in extremely difficult conditions. ${ }^{151}$ For instance, during a Boko Haram attack on Gwoza, Nigeria, in September 2014, an interviewee said she gave birth in the bush while fleeing. ${ }^{152}$ According to numerous interviews conducted by OHCHR in Nigeria, several women died during childbirth or were forced to abandon their new born babies as they escaped attacks in Baga, Gwoza, and Michika. ${ }^{153}$ A woman, who was rescued from Sambisa forest, informed OHCHR that she witnessed births by 10 women while held captive in the various Boko Haram strongholds. ${ }^{154}$ These are clear violations of the rights to birth control, access good-quality reproductive healthcare and the right to make education and access in order to make free and informed reproductive choices as enshrined in Article 14 (1) of the Maputo Protocol, which guarantees the health and reproductive rights of women. ${ }^{155}$ According to Amnesty International, violence against women violates their bodily integrity because a woman's right to control her sexuality and reproduction is a basic human right. ${ }^{156}$

\section{CONSEQUENCES ON HUMAN RIGHTS LAW AND HUMANITARIAN LAW}

The various nefarious acts of the sect and counter-insurgency measures by the Nigerian State amounts to gross violations of international human rights law and international humanitarian law as applicable to non-international conflict. Humanitarian law and Human Rights law are closely related. Both have common values, which are primarily those of respect for and dignity of human persons though Humanitarian Law is concerned with the regulation of armed conflict.

In non-international armed conflict such as the Boko Haram insurgency, both human rights law and humanitarian law are applicable. It follows therefore, that the Nigerian state remains bound by its obligations under international human rights law, while all parties to the conflict, including the Boko Haram sect as a non-state armed group, are bound by the rules of international humanitarian law. Thus both parties to the conflict are responsible for violations of international humanitarian law. Serious violations of international humanitarian law constitute war crimes and entail individual criminal responsibility. Certain crimes, when committed as part of a widespread or systematic attack directed against any civilian population (in furtherance of a state or organizational policy), with knowledge of the attack,

\footnotetext{
${ }^{150} \mathrm{OHCRC}$ op cit

151 Ibid

152 Ibid

153 Ibid

154 Ibid

155 This Article provides that -

(1) States Parties shall ensure that the right to health of women, including sexual and reproductive health is respected and promoted. This includes:

a) the right to control their fertility;

b) the right to decide whether to have children, the number of children and the spacing of children;

c) the right to choose any method of contraception;

d) the right to self-protection and to be protected against sexually transmitted infections, including HIV/AIDS;

e) the right to be informed on one's health status and on the health status of one's partner, particularly if affected with sexually transmitted infections, including HIV/AIDS, in accordance with internationally recognised standards and best practices;

g) the right to have family planning education.

156 Amnesty International, USA, 'Sexual and Reproductive Health Rights'. Available at www.reproductiverights.org/sites. Accessed on 7th April, 2016
} 
constitute crimes against humanity, which also warrant and entail individual criminal responsibility. ${ }^{157}$

The female gender is protected under international humanitarian law. Violence to life and persons, inhuman treatment, the taking of hostages, collective punishments, slavery and punishments are prohibited. ${ }^{158}$ There are special protections covering particular categories such as the wounded and sick, medical and religious personnel, women and children. ${ }^{159}$ It can be garnered that humanitarian law in this context is to mitigate the effect of the insurgency on the female gender.

Furthermore, the protection from human rights violations and security of a person especially that of a member of the female gender is a basic human right that is globally recognized and also a fundamental duty of the State. ${ }^{160}$ Consequently, the Nigerian state is required to respect, safeguard and guarantee the human rights of its citizens. It also has a duty to ensure that victims of human rights and humanitarian violations, their dependants and families have a right to reparation, in order to address the damage and pain they have suffered. Such reparation includes restitution, compensation, rehabilitation, medical care and psychological aid. Furthermore, it is also duty bound and obligated under the Rome Statute of the International Criminal Court (ICC) and International Law to bring the violators of human rights and humanitarian law to justice through the investigation and prosecution of crimes committed by both parties to the conflict. ${ }^{161}$

Examples of members of the deadly sect prosecuted and convicted so far, include that of Kabiru Umar alias Kabiru Sokoto, a member of the Shura (Decision Making) Council of the Boko Haram sect and mastermind of the Christmas day bombing of St. Theresa Catholic Church, Madalla, Niger State in 2011, that killed at least 44 worshippers were killed while 70 others sustained injuries. ${ }^{162} \mathrm{He}$ was convicted for the offences of murder and terrorism, and subsequently sentenced to life imprisonment on $20^{\text {th }}$ December, 2013 by the Federal High Court.

Another trite example is the prosecution and conviction of three members of the deadly sect in the persons of Ali Muhammed, Adamu Kurumi and Ibrahim Usman. These men were sentenced to twenty-five (25) years imprisonment with hard labour for participating in acts of terrorism, conspiracy to commit terrorism, illegal possession of firearms and being members of a proscribed organization. These offences contravene the provisions of Sections 13(2) and 17(b) of the Terrorism Act, 2013 and Sections 1, 8, 27 (1) (a) and (b) of the Firearms (Special Provisions) Act, Cap F. 28, Laws of the Federation 2004. ${ }^{163}$ In this case Seventeen (17)

\footnotetext{
${ }^{157}$ ICRC Customary IHL Study, Rule 156. See further the case of The Prosecutor v. Dusko Tadić, Case No. IT94-1-AR72, ICTY Appeals Chamber, 2 October 1995

${ }^{158}$ Articles 75 and 4 of the Additional Protocols I and II to the Geneva Convention of 1949 respectively

${ }^{159}$ Articles 10, 15, 76, 77 of the Additional Protocol I and Articles 7 - 9 of the Additional Protocol II to the Geneva Convention of 1949

${ }^{160}$ St. Emmanuel op cit at 219

${ }^{161}$ United Nations Basic Principles and Guidelines on the Right to a Remedy and Reparation for Victims of Gross Violations of International Human Rights Law and Serious Violations of International Humanitarian Law. Adopted and proclaimed by General Assembly resolution 60/147 of 16 December 2005. See also Paragraphs (4) and (6) of the Preamble to the Rome Statute of the International Criminal Court

162 The Leadership Newspaper, Kabiru Sokoto: Police Reverses Zakari Biu's Dismissal, Promotes 2 CPs to AIGs. Available at http://.leadership.ng/news/458770/kabiru-sokoto-police-reverses-zakari-bius-dismissalpromotes-2-cps-to-aigs. accessed on 31st March, 2016. See also The Nation Newspaper, Xmas Day Bomber, Kabiru Sokoto gets Life Sentence. Available at http://thenationonlineeng.net/xmas-day-bomber-kabir-sokotogets -life-sentence/ accessed on 31st March, 2016

163 The Leadership Newspaper, Court Jails Boko Haram Members 75 Years for Terrorism. Available at http://.leadership.ng/news/385644/court-jails-boko-haram-members-75-years-terrorism. accessed on 31st March, 2016.
} 
suspects were charged to Court by the Lagos State Government but were later reduced to four (4) due to the withdrawal of the case against thirteen (13) suspects. ${ }^{164}$

From the foregoing, it can be deduced that little has been done by the Nigerian State in this regard. In an earlier work, St. Emmanuel posits that victims, their dependants and families have an alternative means of bringing their assailants to justice vide prosecuting the violators before the International Criminal Court. ${ }^{165}$

The International Criminal Court has jurisdiction over the violations of human rights of the female gender by the Boko Haram sect and Nigerian Military because they amount to war crimes and crimes against humanity such as pillaging of towns, displacement of civilian population, rape and other forms of sexual violence. ${ }^{166}$ The ICC also has jurisdictions over individuals, whether civilians or military and regardless of rank, who have committed serious violations of international humanitarian law during the conflict. Consequently, violators can be found guilty individually (that is, individual criminal responsibility) ${ }^{167}$ and likewise, commanders and superiors for crimes committed under their watch. ${ }^{168}$

A good example here is the ad hoc Tribunal for Former Yugoslavia (ICTY) recognizing a direct form of individual criminal liability which was derived from "committed" and is known as joint criminal enterprise (JCE). ${ }^{169}$ In Prosecutor $\boldsymbol{v}$. Kristic, ${ }^{170}$ the ICTY declared that General Kristic was responsible for several cases of murders and rapes as "there is no doubt that these crimes were the natural and foreseeable consequences of the ethnic cleaning campaign. Given the circumstances at the time the plan was formed, General Kristic must have been aware an outbreak of these crimes would be inevitable given the lack of shelter, the density of the crowds, the vulnerable condition of the refugees, the presence of the regular and irregular military and paramilitary units in the area and the sheer lack of sufficient numbers of UN soldiers to provide protection" $" 171$

Also in Prosecutor v. Blaskic, ${ }^{172}$ the ICTY stated that Colonel Blaskic's liability was based on superior responsibility. He was found guilty of war crimes on the basis that sexual violence was foreseeable when barracking his troops in a school were civilian women were located. He "could not have been unaware of the atmosphere of terror and rape which occurred at the school." 173

According to Sellers, this approach of recognizing the fore-seeability of sexual violence, provides a useful, lucid framework for joint liability, especially for perpetrators who are physically far removed from the locations of sexual assault crimes, including military and political leaders. ${ }^{174}$

\footnotetext{
${ }^{164}$ Ibid. These other thirteen suspects are Idris Ali, Mohammed Murtala, Kadiri Mohammed, Mustapha Daura, Abba Duguri, Sanni Adamu, Danjuma Yahaya, Musa Audu, Mati Daura, Farouk Haruna, Abdullahi Azeez, Ibrahim Bukar and Zula Diani. The $17^{\text {th }}$ person, Bala Haruna, was discharged by the court on the ground that Lagos State Government failed to prove the allegation of funding of terrorism leveled against him.

165 St. Emmanuel op cit at $236-237$

${ }^{166}$ Article 5 (1) (c) and Article 8 (2) (e) (iv) of the Rome Statute of the ICC

${ }^{167}$ Article 25 of the Rome Statute of the ICC

168 Article 28 of the Rome Statute of the ICC

${ }^{169}$ ECCHR op cit at 9

${ }^{170}$ Judgement, Case No. IT-98-33-T, 2 August 2001. Sexual violence formed a part of the basis of the conviction of Krstic for persecution as crime against humanity. He was the chief of staff and later commander of a Bosnian Serb army corps cited in ECCHR op cit at 10

171 Ibid at para. 615

172 IT-95-14-T, 3 March 2000. Findings referring to rape committed against civilians in Bosnia Herzegovina were made in the trial judgment. These findings did not relate to specific sexual-violence charges. They included findings on multiple rapes of Bosnian Muslims by Bosnian Croat forces in a vil-lage; multiple rapes of detained Bosnian Muslim women by Croatian forces and police; and a finding that the accused could not have been unaware of rapes at certain school

${ }^{173}$ Ibid at para. 732 .

${ }^{174}$ Sellers, V, OHCHR, WRGUS, 16 cited in ECCHR op cit at 9
} 
Furthermore, it is worth noting that war crimes are crimes under international law because they are directed against the interests of the entire international community, thus the International Criminal Court is empowered to prosecute and punish these crimes, not considering who committed them or against whom they were committed. ${ }^{175}$ Though the Nigerian State is yet to domesticate the Rome Statute of the International Criminal Court which it ratified on $27^{\text {th }}$ September, 2001, ${ }^{176}$ the International Criminal Court has jurisdiction over war crimes committed on the territory of Nigeria or by its Nationals from $1^{\text {st }}$ July 2002 onwards. ${ }^{177}$ There is a pending Bill for an Act to provide for the Enforcement and Punishment of Crimes against Humanity, War Crimes, Genocide and Related Offences and to give effect to certain Provisions of the Rome Statute of the International Criminal Court in Nigeria, 2013 before the National Assembly. This Bill provides inter alia; for the punishment of those responsible for international crimes in Nigeria and cooperation between Nigeria and the ICC to ensure the effective investigation and prosecution of criminals. ${ }^{178}$ The Bill also provides for a Special Victims Trust Fund (SVTF) to assist victims, their families and survivors of international crimes in Nigeria. ${ }^{179}$

As at $1^{\text {st }}$ of June, 2013, the Office of the Prosecutor of the International Criminal Court received sixty-five (65) Article $15^{180}$ communications pertaining to the Boko Haram insurgency in Nigeria, out of which Twenty-Six (26) were not within the jurisdiction of the court. ${ }^{181}$ Five (5) were found to warrant further analysis, while twenty-eight (28) communications were included in the preliminary examinations. ${ }^{182}$

The results of the preliminary examinations were made public on $18^{\text {th }}$ day of November, $2010 .{ }^{183}$ The office of the prosecutor has further decided that the preliminary examination of the situation in Nigeria should advance to phase 3 (admissibility) with a view to accessing whether the Nigerian State is conducting genuine proceedings against the perpetrators, because there is a reasonable cause to believe that crimes against humanity such as murder and persecution have been committed. ${ }^{184}$ It is also worth mentioning that, crimes under the purview of the ICC are not subject to any statute of limitation. ${ }^{185}$

According to Adeogun-Philips, the trial of members of the Boko Haram Sect and the Military at the ICC should not be the only option open to the Nigerian Government because it is of great importance to the international community that justice must not only be done but

\footnotetext{
${ }^{175}$ Werle G, Principles of International Criminal law, T. M. C Asser Press, The Hague, 2005, 58

176 The Nigerian Government drafted a bill titled 'Crimes against Humanity, Genocide and Related Offences Bill, 2012 to implement the Rome Statute. This Bill passed the first reading and got to the stage of second reading in Mat, 2013. <http://www.pgaction.org/campaigns/icc/africa/nigeria.html> accessed on $4^{\text {th }}$ April, 2016. ${ }^{177}$ Available at https://www.icccpi.int/en_menus/iccstructure $\% 20 \mathrm{of} \% 20$ the $\% 20$ court/office $\% 20 \mathrm{of} \% 20$ the $\% 20$ prosecutor/comm\%20and $\% 20 \mathrm{ref} /$ pe-ongoing/nigeria/pages/nigeria.aspx accessed on 1st April, 2016

${ }^{178}$ Section 2 of the proposed Crimes against Humanity, War Crimes, Genocide and Related Offences Bill, 2012

${ }^{179}$ Section 93 of the proposed Crimes against Humanity, War Crimes, Genocide and Related Offences Bill, 2012

${ }^{180}$ Article 15 (1) and (2) of the Rome Statute of the ICC provides as follows:

1. The Prosecutor may initiate investigations proprio motu on the basis of information on crimes within the jurisdiction of the Court.

2. The Prosecutor shall analyse the seriousness of the information received. For this purpose, he or she may seek additional information from States, organs of the United Nations, intergovernmental or nongovernmental organizations, or other reliable sources that he or she deems appropriate, and may receive written or oral testimony at the seat of the Court.
}

183 Ibid

${ }^{184}$ Ibid

185 Articles 15 (5) and 29 of the Rome Statute of the ICC 
must be seen by all Nigerians to be done., following the magnitude of the insurgency. ${ }^{186}$ Adeogun-Philips posited further that this cannot only be achieved by a trial at The Hague. ${ }^{187}$ Adeogun-Philips concludes that the Nigerian Government must be given the opportunity to demonstrate its ability and/or willingness to investigate and prosecute members of Boko Haram and the Military for war crimes through the use of a "localised" International Court rather than lean towards an ICC prosecution. ${ }^{188}$

\section{RECOMMENDATIONS}

Just like in any other society of the world, Nigerian women are attributed with different traditional roles, such as wife, mother and nurturer and as such they are empowered in some instances to be custodians of cultural, religious and social values. ${ }^{189}$ Consequently, Fink, Barakat and Shetrat posits that women are in a unique position, which they can use to radicalize, glorify and encourage family members and children to seek martyrdom and keep terrorist organizations viable through support activities such as propaganda, fund raising and recruitment. ${ }^{190}$ They posit further that, women can also be powerful preventers, who can partake in innovative endeavours to inform, shape and implement policies and programmes to alleviate the consequences of conflict and violent radicalization. ${ }^{191}$ It follows therefore that members of the female gender should be empowered economically to participate in policy development dialogue and programmes because when empowered they will possess more influence in their homes, communities and the nation at large. Sequel to the foregoing, the following recommendations and suggestion are hereby submitted as solutions in protecting the rights of members of the female gender during the ongoing Boko Haram insurgency -

- The Nigerian National Assembly should enact into law, 'A Bill for an Act to provide for the Enforcement and Punishment of Crimes against Humanity, War Crimes, Genocide and Related Offences and to give effect to certain Provisions of the Rome Statute of the International Criminal Court in Nigeria, 2013 (SB 183)

- The Nigerian government should undertake a national security policy that will be gender based and protect the rights of women and girls in order to assess and mitigate the impact of insurgency. A gender perspective should also be adopted into counterinsurgency operations through the increase in the number of female law enforcement practitioners. It is opined that female law enforcement personnel will understand gender sensitivities and will therefore be able to extract intelligence and accomplish results.

- The Nigerian State should also partner and create multinational synergies with world superpowers to facilitate the rescue and return of abducted members of the female gender. In addition, the government should facilitate the rehabilitation and reintegration of such rescued persons.

\footnotetext{
${ }^{186}$ Adeogun-Phillips, C, Nigeria: Boko Haram/JTF - Justice must be done and be seen by all Nigerians to be done. Available at http://allafrica.com/stories201408211030.html. accessed on 6th April, 2016.

187 Ibid

${ }^{188} \mathrm{Ibid}$. Adeogun-Philips is of the opinion that a good example of a 'localised' international court will be the establishment of an International Crimes Division, as a vital part of the Federal High Court, Abuja Judicial Division. He opines further that the said court should be composed of local judges, investigators, ;registrars and prosecutors appointed from within the local personnel but equipped with proper training on adjudicating and prosecuting cases bordering on the commission of international crimes. Adeogun-Philips also believes that it is the full participation of citizens from affected countries that differentiates a 'localised' international court from other international criminal courts.

${ }^{189}$ Fink, N. C; Barakat, F \& Shetret, L; "The Roles of Women in Terrorism, Conflict, and Violent Extremism: Lessons for the United Nations and International Actors" Policy Brief (2013) Center on Global Counterterrorism Cooperation 4. Available at www.globalcenter.org/.../NCF_RB_LS_policybrief_1320.pdf. accessed on 16th January, 2016

${ }^{190}$ Ibid

191 Ibid
} 
- Furthermore, the Nigerian State should adopt an intelligence approach in combating the insurgency because this will be an effective way to put an end to the insurgency and also a means to mitigate the effect of the insurgency on the female gender.

- The Nigerian State should tackle the causes of the insurgency such as corruption, unemployment, poverty and economic inequality.

- The Nigerian State should independently, impartially and thoroughly investigate the allegations of gross violations of human rights by its military and prosecute those found guilty.

- Both the Boko Haram sect and Nigerian government should abide and comply with their duties and obligations under human rights law and humanitarian law respectively and stop unlawful targeting of women such as torture, killing, abduction, and unlawful detention of women and indiscriminate and proportionate attacks on women.

\section{CONCLUSION}

This work examined the implications and effects of the ongoing sectarian Boko Haram insurgency and reveals that the Nigerian government has a duty, under International Law to prevent, investigate and punish human rights violations perpetrated by state and non-state actors that is the Nigerian Military and Boko Haram sect respectively. The paper submits that the Nigerian State has disregarded this obligation by not addressing human rights abuses perpetrated on the female gender with impunity by its military and the deadly sect in particular. It submits further that the fight against Boko Haram insurgency should also be a fight for the protection of the rights and dignity of women because it is the women and children who bear the brunt of, and are mostly caught in the web of the insurgency and counter-insurgency measures.

It is trite that before the Boko Haram insurgency, women and girls in Northern Nigeria faced gender inequality, discrimination, high illiteracy level due to antipathy towards the education of the girl child, soaring maternal mortality rate and domestic violence but their rights are still indivisible, universal, inalienable and non-negotiable, hence the need for administrative dexterity and taken of pragmatic steps to ensure women equality and protection of the rights of women. The paper concludes that women should also be involved in peace making processes because there can be no peace without the female gender. 